\title{
Biogeochemical implications for phosphorus cycling in sandy and muddy rhizosphere sediments of Zostera marina meadows (Denmark)
}

\author{
Marianne Holmer*, Cristiana Carta, Frede Ø. Andersen \\ Institute of Biology, University of Southern Denmark, Campusvej 55, 5230 Odense M, Denmark
}

\begin{abstract}
To date, few studies have investigated the implications of sediment biogeochemical conditions on differences in sediment phosphorus (P) pools and P availability in sandy (low-P) and muddy (high-P) siliclastic seagrass sediments. To determine the role of seagrass activity on seasonal changes in sedimentary $\mathrm{P}$, we investigated the solid-phase $\mathrm{P}$ pools in seagrass Zostera marina sediments in a Danish fjord. During the $Z$. marina growth season sediments were fractionated by sequential extractions into 3 (and once into 5) chemically defined groups: loosely adsorbed inorganic $\mathrm{P}_{\text {, inor- }}$ ganic $\mathrm{P}$ bound to oxidized metals (primarily Fe-bound), P adsorbed to clay minerals, Al and humic acids, Ca-bound P, and refractory organic P. Fe-bound P accounted for about $30 \%$ of total P in the muddy sediments, whereas this pool was small in the sandy sediment $(<5 \%)$. Here the Ca-bound pool was the most important ( $>80 \%$ ). The Fe-bound P at the muddy site showed seasonal variations with lower pools during late summer, and it was always lower in the vegetated sediment, except during maximum biomass in July, where Fe-bound P was higher in the deep rhizosphere sediments. The seasonal variation was less at the sandy site, and there was little difference between unvegetated and vegetated sites, suggesting that the vegetation had a limited effect on the sedimentary P pools. However, the presence of vegetation increased the availability of $\mathrm{P}$ in the water column at both types of site, as $\mathrm{P}$ was released across the sediment-water interface at the vegetated sites compared with an uptake during most of the sampling period at the unvegetated sites, although the fluxes were low and could only account for a minor fraction $(<10 \%)$ of the seasonal changes in the sedimentary P pools. Estimates of $\mathrm{P}$ incorporation in seagrass biomass showed that the seasonal variation in sedimentary $\mathrm{P}$ pools were more than sufficient to support the P demand. We hypothesize that the higher P contents in seagrass tissues and the larger biomass at the muddy site are due to high $\mathrm{P}$ availability from the redox-sensitive Fe-bound and organic P pools at this site, whereas P may be a limiting factor for growth at the sandy site, where the mobility of $\mathrm{P}$ is lower due to binding in the Ca fraction.
\end{abstract}

KEY WORDS: Phosphorus · Zostera marina $\cdot$ Sediment $\cdot$ Nutrient content $\cdot$ Seasonal variation

\section{INTRODUCTION}

Sediments of aquatic ecosystems play a key role in phosphorus (P) cycling between dissolved- and solidphase pools, and control long-term $\mathrm{P}$ diagenesis. The major biogeochemical processes that transform inorganic P from a dissolved to a solid state include anion adsorption, precipitation/co-precipitation with elements such as calcium, iron and aluminum, and uptake by microbes and plants. In tropical and subtropical areas dominated by carbonate sediments, formation of calcium-phosphate complexes may effectively make P non-accessible for seagrasses, whereas $\mathrm{P}$ is considered to be more mobile and available in siliclastic sediments due to binding to the redox-sensitive Fe-P complexes (Jensen et al. 1995, 1998). The redox state and chemical composition of the sedimentary iron pools in siliclastic sediments can significantly influence the avail- 
ability of phosphate in the porewater and the release of phosphate across the sediment-water interface (Jensen et al. 1995, Azzoni et al. 2001). When sediments are enriched with organic matter, e.g. due to eutrophication, this may stimulate bacterial metabolism and in particular sulphate reduction, which can be the dominant carbon-oxidation pathway in coastal marine sediments (Canfield 1993). In sediments vegetated with rooted macrophytes, the availability of porewater phosphate for plants is indirectly linked to rates of sulphide production and reoxidation, as the reduction of ferric iron or the binding of iron into iron sulphides causes a release of the adsorbed phosphate (Roden \& Edmonds 1997). This mechanism can provide a feedback between sediments and the water column, with increased phosphate fluxes stimulating primary productivity in the water column, which in turn fuels microbial activity in the sediments, causing further decreases in the sediment redox status and hence greater phosphate availability. In addition, sulphide produced during sulphate reduction is toxic (Azzoni et al. 2001) and may negatively effect growth of seagrasses (Holmer \& Laursen 2002). P availability may, however, not always be influenced by the redox state in siliclastic sediments. Because sandy sediments are typically dominated by carbonates and silicates and have low iron contents compared with clay-dominated sediments, redox reactions may be of little importance in controlling sediment $\mathrm{P}$ transformations. To date, few studies have investigated sedimentary P pools or identified the chemical processes important in the P cycle in temperate seagrass meadows growing on different substrates.

Seagrasses form highly productive communities on a variety of substrates. Thus, eelgrass Zostera marina is abundant in temperate regions, e.g. from the Baltic Sea to northern Spain, and has a wide distribution from coarse-grained sandy sediments near the intertidal limit to fine-grained muddy sediments at deep locations. Most seagrasses are capable of absorbing nutrients from both sediment and water-column sources, but it has been assumed that nutrient uptake by roots dominate over leaf uptake in estuaries where porewater nutrient concentrations are high relative to surface waters (Brix \& Lyngby 1985, Hemminga 1998, Sfriso \& Marcomini 1999, Touchette \& Burkholder 2000). However, for plants growing in P-rich waters or sandy Ppoor sediments, $\mathrm{P}$ uptake by leaves can be higher than by roots (McRoy \& Barsdate 1970, Thursby \& Harlin 1984, Gras et al. 2003).

While nitrogen is not considered a limiting factor for seagrass growth in the N-rich coastal waters of Denmark (Pedersen \& Borum 1992, Nielsen et al. 2002), knowledge about $\mathrm{P}$ limitation in this area is rather limited, but it has been suggested that growth of Zostera marina on coarse-grained low-P substrates may be Plimited in the same way as tropical and subtropical seagrasses growing on carbonate sediments (Alcoverro et al. 1997, Jensen et al. 1998, Gras et al. 2003) because of the strong binding of $\mathrm{P}$ in calcium fluoroapatite (Jensen et al. 1998). There is no detailed information available on the seasonal changes in $\mathrm{P}$ forms, fluxes between sediment and water, and $\mathrm{P}$ availability in $Z$. marina meadows, but growth and biomass of $Z$. marina has shown positive responses to fertilization with $\mathrm{P}$, indicating $\mathrm{P}$ limitation (Murray et al. 1992).

The purpose of the present study was to examine the forms and availability of sedimentary $\mathrm{P}$ in 2 eelgrass meadows with contrasting substrates (sandy vs. muddy sediment) during the maximum growth period (June to September). Biogeochemical parameters such as sediment organic content, redox profiles and pools of sulphides (free sulphides, iron monosulphides and pyrite) were also measured to assess their effects on P dynamics and in particular on the redox-sensitive pools of the sedimentary P. A sequential extraction of the sedimentary P pools was undertaken during the growth season with focus on the most mobile pools during 3 samplings (loosely adsorbed $\mathrm{P}$ and Fe-bound $\mathrm{P}$ ) and a full sequential extraction was made at the end of the season (also including adsorbed $\mathrm{P}, \mathrm{Ca}-\mathrm{bound} \mathrm{P}$ and organically bound $\mathrm{P}$ ) in unvegetated and vegetated sediments. The sediment metabolic activity and flux of $\mathrm{P}$ across the sediment-water interface were studied in sediment incubations. The sedimentary $\mathrm{P}$ dynamics were related to the seasonal changes in biomass and nutrient content of the seagrasses.

\section{MATERIALS AND METHODS}

Study area and sampling procedures. Sediments and plants were collected during the maximum growth season between June and September in 2004 at a coastal site on the southwest coast of Fyn in Lillebælt, Denmark $\left(55^{\circ} 28.958^{\prime} \mathrm{N}, 9^{\circ} 43.956^{\prime} \mathrm{E}\right)$. The stations were at shallow depths $(\sim 1 \mathrm{~m})$ with eelgrass Zostera marina present in patches, and the sediments were either sandy or muddy, the sandy site being wind exposed. The water quality was assumed to be similar at the 2 sites, as the stations were located within $500 \mathrm{~m}$ of each other in a strait where tides reverse every $6 \mathrm{~h}$. Sediment samples (3 replicates) from each station were collected manually using acrylic cores (inner diameter $8 \mathrm{~cm}$, length $32 \mathrm{~cm}$ ) in eelgrass meadows and in adjacent bare sediments. The cores were brought to the laboratory and stored at $15^{\circ} \mathrm{C}$ in a tank with aerated water from the sampling site. The water level in the tank was at least $2 \mathrm{~cm}$ above the upper edge of the 
cores. Each core was fitted with a stirring magnet (60 rpm), and the tank water was aerated using several air-pumps. The cores were kept in darkness.

Plant measurements. Eelgrass density and aboveground biomass were determined within 3 randomly positioned rings $\left(0.08 \mathrm{~m}^{2}\right)$ at each station. The shoots were harvested inside the rings and transported back to the laboratory, where the shoot density was quantified. The below-ground biomass was determined only in September by analysing 3 cores from the eelgrass meadows. The cores were sectioned in the intervals $0-1,1-5,5-10$ and $10-15 \mathrm{~cm}$ and sieved. The plant material was then separated into root and rhizome. Dry weight (DW) of plant material was determined by drying to constant weight at $60^{\circ} \mathrm{C}$. Before nutrient analysis, the eelgrass tissues were ground to a powder, and organic carbon (POC) and nitrogen (TN) were determined by elemental analysis on a Carbo Erba Elemental Analyser 1100EA. For total phosphorus (TP), approximately 0.06 to $0.08 \mathrm{~g}$ (triplicates for each sample) was ignited at $520^{\circ} \mathrm{C}$ for $2 \mathrm{~h}$ and subsequently boiled at $120^{\circ} \mathrm{C}$ for $1 \mathrm{~h}$ in $8 \mathrm{ml}$ of $1 \mathrm{M} \mathrm{HCl}$, after which dissolved inorganic phosphate (DIP) was measured spectrophotometrically using the molybdate blue method (Koroleff 1983).

Sediment flux measurements $\left(\mathrm{O}_{2}\right.$ and DIP). Sediment oxygen uptake (SOU) was determined by shortterm incubations ( 3 to $4 \mathrm{~h}$ ) of the collected sediments cores 1 to $2 \mathrm{~d}$ after sampling. An initial sample $\left(T_{0}\right)$ was taken from the water phase inside each core while still submerged, and oxygen $\left(\mathrm{O}_{2}\right)$ was determined according to the Winkler method. A gas-tight lid was placed on top of the cores, while underwater, and the height of the water phase in cores was noted. At termination of the incubation, after 3 to $4 \mathrm{~h}$, the final sample $\left(T_{1}\right)$ was taken from each core, and the $\mathrm{O}_{2}$ uptake was calculated from the decline in $\mathrm{O}_{2}$ concentration. Fluxes of DIP were obtained similarly, except that the top of the sediment cores was kept above the water level in the tank, the water column was kept aerated, and the incubation was prolonged to about $24 \mathrm{~h}$. The samples were GF/C filtered and stored frozen until analysis as described above.

Redox potential. After termination of the flux incubations, redox potential $\left(E_{\mathrm{h}}\right)$ profiles were measured with a Pt electrode using a calomel electrode as reference. $E_{\mathrm{h}}$ was recorded in the water column at $2 \mathrm{~cm}$ above the sediment and at 0.5, 3.0, 7.5 and $12.5 \mathrm{~cm}$ depth in the sediment.

Sequential extraction of $\mathbf{P}$ and Fe pools. After redox measurements were taken, the sediment cores were sliced in the intervals $0-1,1-5,5-10$, and $10-15 \mathrm{~cm}$ in a glove bag in an $\mathrm{N}_{2}$ atmosphere to prevent oxidation of iron and sulphides. Phosphorus was extracted according to Jensen \& Thamdrup (1993), with a few modifications. Approximately $1 \mathrm{~g}$ of wet sediment from each slice was subsampled and transferred to a $50 \mathrm{ml}$ polyethylene centrifuge tube, where replicate samples from the 3 sediment cores from bare and vegetated sites were pooled, respectively. In Step 1, $1 \mathrm{M} \mathrm{MgCl}_{2}$ ( $\mathrm{pH}$ 8) was added to the sediment to extract loosely adsorbed $\mathrm{P}$ and porewater $\mathrm{P}\left(\mathrm{P}_{\mathrm{MgCl}_{2}}\right)$. In Step 2, sodiumbicarbonate-buffered dithionite solution (BD-reagent: $0.11 \mathrm{M} \mathrm{NaHCO}_{3}+0.11 \mathrm{M} \mathrm{Na}_{2} \mathrm{~S}_{2} \mathrm{O}_{4}$ ) was added to the sediment pellet to extract phosphate bound to reducible forms of iron and manganese $\left(\mathrm{P}_{\mathrm{BD}}\right)$. Steps 1 and 2 were carried out in an $\mathrm{N}_{2}$ atmosphere. In Step 3, the sediment was extracted with $0.1 \mathrm{M} \mathrm{NaOH}\left(\mathrm{P}_{\mathrm{NaOH}}\right)$. This step is supposed to extract phosphate adsorbed to clay minerals, Al oxides and humic acids. In Step 4, the sediment was shaken with $0.5 \mathrm{M} \mathrm{HCl}$ to extract calcium-bound $\mathrm{P}\left(\mathrm{P}_{\mathrm{HCl}}\right)$. In Step 5 the remaining sediment pellet was dried and combusted at $520^{\circ} \mathrm{C}$ for $6 \mathrm{~h}$ and subsequently boiled in $8 \mathrm{ml}$ of $1 \mathrm{M} \mathrm{HCl}$ at $120^{\circ} \mathrm{C}$ for $1 \mathrm{~h}$ to extract the residual $\mathrm{P}$. This pool represents the most refractory part of the organic $\mathrm{P}$ components $\left(\mathrm{P}_{\mathrm{RES}}\right)$. The extracted inorganic phosphate was measured as described above for DIP. Only Steps 1, 2 and 5 were executed in June, July and August, whereas all the steps were completed in September to get a detailed description of all the pools once at each station. To determine the amount of non-reactive P (NRP) leached in Steps 1 to 3, the extracts were subjected to wet oxidation by heating the sample with persulphate for $30 \mathrm{~min}$ at $105^{\circ} \mathrm{C}$ in an autoclave, after which TP was measured. NRP, which is supposed mainly to consist of organically bound $\mathrm{P}$, was calculated as the difference between the TP and DIP. As NRP contents were low ( $<1 \%$ of TP), only TP values are presented for the first 3 steps.

Fe concentrations were determined in the $\mathrm{BD}$, $\mathrm{NaOH}, \mathrm{HCl}$ and RES extracts $\left(\mathrm{Fe}_{\mathrm{BD}}, \mathrm{Fe}_{\mathrm{NaOH}}, \mathrm{Fe}_{\mathrm{HCl}}\right.$ and $\mathrm{Fe}_{\mathrm{RES}}$, respectively) by spectrophotometric analysis according to Stookey (1970) and Sørensen (1982).

Reduced sulphides (AVS and CRS) pools. Immediately after sediment slicing for the $\mathrm{P}$ and $\mathrm{Fe}$ extractions, $10 \mathrm{ml}$ of sediment from each slice were transferred into $50 \mathrm{ml}$ pre-weighed centrifuge tubes and $10 \mathrm{ml}$ of $1 \mathrm{M}$ zinc acetate was added. The sediment-zinc-acetate mixture was stored frozen and subsequently distilled according to the method of Fossing \& Jørgensen (1989). The distillation separates reduced sulphur compounds in the sediment into 2 pools, namely, acid volatile sulphides (AVS), composed mainly by iron monosulphide (FeS) plus free sulphides, and chromium reducible sulphides (CRS), composed primarily of pyrite $\left(\mathrm{FeS}_{2}\right)$ plus elemental sulphur. For AVS, $8 \mathrm{ml}$ of $6 \mathrm{M} \mathrm{HCl}$ was added to the sediment distillation unit, and the distillation proceeded for $30 \mathrm{~min}$. Zinc-acetate traps were changed, $16 \mathrm{ml}$ of chromium 

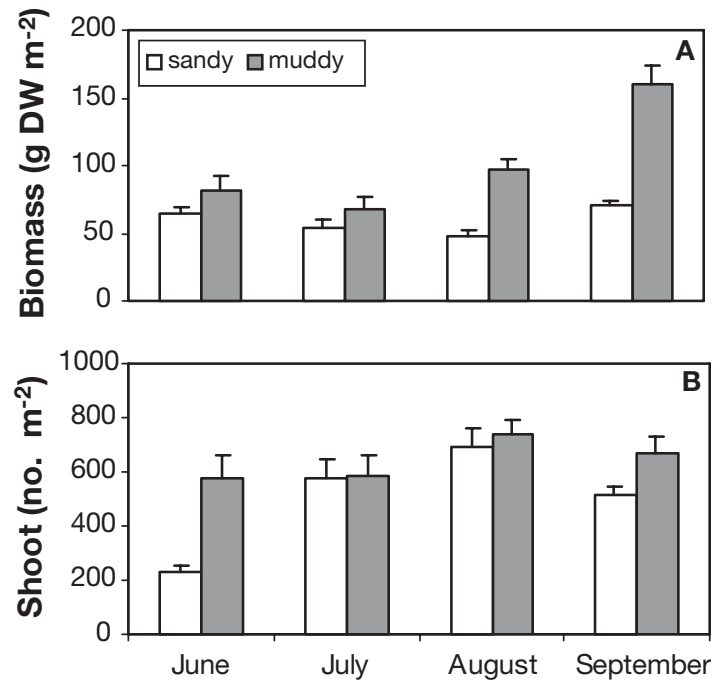

Fig. 1. Zostera marina. Seasonal variation in (A) aboveground biomass and (B) shoot density at the 2 sampling sites $(\mathrm{n}=3,+\mathrm{SD})$

solution was added and the mixture was distilled by boiling for 30 min to obtain the CRS. The sulphide concentrations were measured spectrophotometrically at $670 \mathrm{~nm}$ using the method of Cline (1969).

Density, water content and loss-on-ignition of the sediment. The density of the sediment was determined as the weight of a known volume. The water content was obtained by drying the sediment to constant weight at $105^{\circ} \mathrm{C}$, and loss-on-ignition was obtained after combustion at $520^{\circ} \mathrm{C}$ for $6 \mathrm{~h}$.

\section{RESULTS}

In the early summer the muddy site supported a dense eelgrass population, which remained constant in abundance but approximately doubled in biomass by September (Fig. 1). In contrast, at the sandy site the abundance increased in July and August, whereas the biomass remained almost constant throughout the sampling period (Fig. 1). The below-ground biomass was obtained in September, and for the muddy site $95 \%$ of the biomass was found in the surface layer ( 0 to $5 \mathrm{~cm})$, whereas a smaller fraction (88\%) was found in these layers in the sandy meadow (Fig. 2). The roots penetrated deeper at the muddy site and were present also in the 10 to $15 \mathrm{~cm}$ layer.

The TP content of the above-ground biomass showed distinct seasonal variation at the 2 sites: while the maximum TP content was found at the muddy site in July $(0.404 \pm 0.004 \%$ DW), the content continued to increase at the sandy site throughout $(0.232 \pm 0.005 \%$ DW; Fig. 3A). The TN content showed less seasonal variation and was not different between the 2 sites

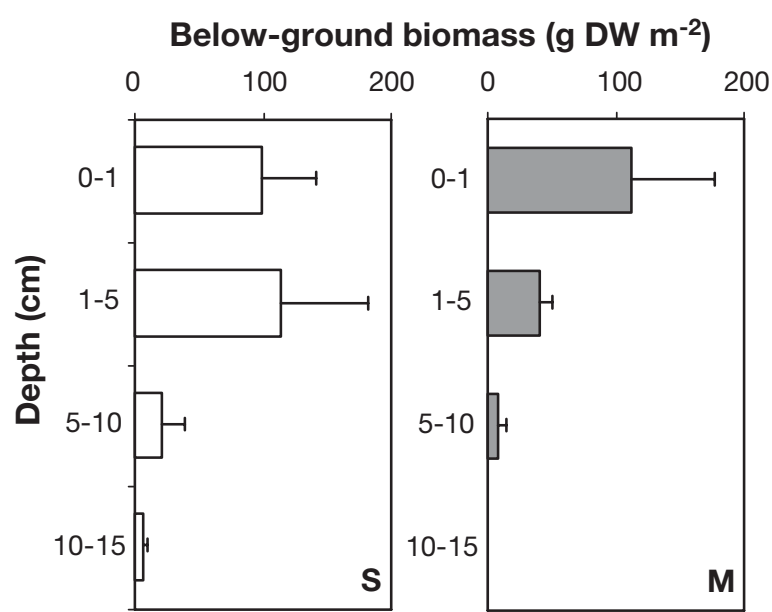

Fig. 2. Zostera marina. Depth profile of below-ground biomass in sandy (S) and muddy (M) sediments sampled in September $(n=3,+\mathrm{SD})$
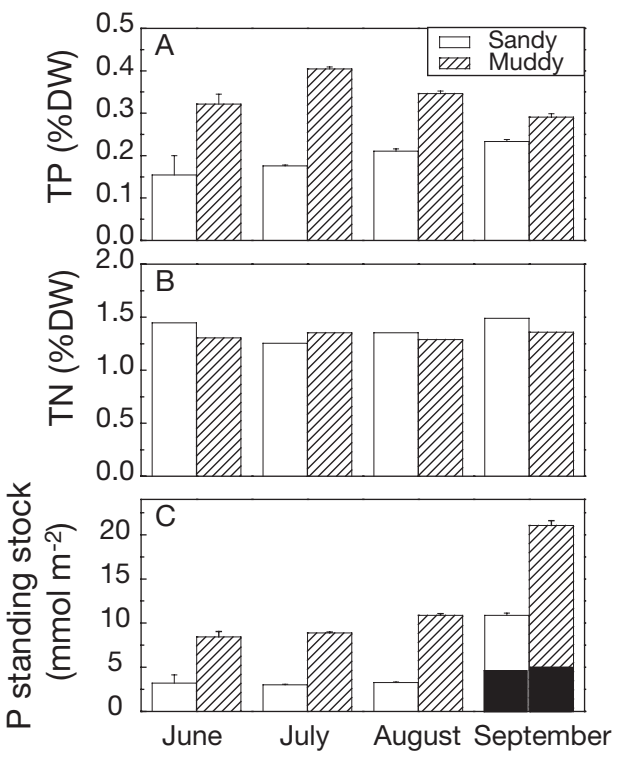

Fig. 3. Zostera marina. Seasonal variation in nutrient concentration and pools in biomass. (A) TP content in leaves $(n=3$, $+\mathrm{SD})$, (B) TN content in leaves $(\mathrm{n}=1)$ and $(\mathrm{C})$ standing stock of TP in leaves and (only for September) below-ground biomass (shown in black; mean, $\mathrm{n}=3,+\mathrm{SD}$ )

(Fig. 3B). The TP content of the below-ground tissues in September at the muddy site was up to 3 times higher $(0.100$ to $0.133 \%$ DW) than at the sandy site (0.059 to $0.075 \% \mathrm{DW})$, with no clear depth pattern at either site (Table 1). The TN content was also up to 3 times higher at the muddy site $(0.82$ to $0.94 \%$ DW) compared to the sandy site $(0.30$ to $0.68 \%$ DW, Table 1). The standing stock of $\mathrm{P}$ in above-ground biomass increased at both sites during the growth season and was almost 2 times higher in September than in June (5.3 and $15.0 \mathrm{mmol} \mathrm{P} \mathrm{m}^{-2}$ at the sandy and muddy 
Table 1. Total P (TP) and total N (TN) concentrations in below-ground tissues at the sandy and muddy sites during sampling in September (average of 3 pooled cores). Molar concentrations are given in parentheses. -: no roots present

\begin{tabular}{|c|c|c|c|c|}
\hline \multirow{2}{*}{$\begin{array}{l}\text { Depth } \\
\text { interval } \\
(\mathrm{cm})\end{array}$} & \multicolumn{2}{|c|}{$\begin{array}{c}\text { TP } \\
\% \mathrm{DW}\left(\mu \mathrm{mol} \mathrm{g} \mathrm{DW} \mathrm{DW}^{-1}\right)\end{array}$} & \multicolumn{2}{|c|}{$\begin{array}{c}\mathrm{TN} \\
\% \mathrm{DW}\left(\mu \mathrm{mol} \mathrm{gWW}^{-1}\right)\end{array}$} \\
\hline & Sandy & Muddy & Sandy & Muddy \\
\hline $0-1$ & $0.075(24.2)$ & 0.100 (32.3) & $0.302 \quad(215.7)$ & $0.818 \quad(584.3)$ \\
\hline $1-5$ & 0.059 (19.0) & 0.133 (42.9) & $0.343(245.0)$ & 0.939 (670.7) \\
\hline $5-10$ & $0.071 \quad(22.9)$ & $0.110(35.5)$ & $0.681(486.4)$ & $0.848 \quad(605.7)$ \\
\hline $10-15$ & $0.064 \quad(20.6)$ & $-\quad-$ & $0.540(385.7)$ & $-\quad-$ \\
\hline
\end{tabular}

Fig. 4. Seasonal variation in sediment oxygen uptake (SOU) in vegetated (eelgrass Zostera marina) and bare sediment from sandy $(\mathrm{S})$ and muddy $(\mathrm{M})$ sites $(\mathrm{n}=3,+\mathrm{SD})$

sites, respectively; Fig. 3C). The below-ground pool accounted for 34 and $21 \%$ of the total pool at the sandy and muddy site, respectively.

In general, SOU was highest at the muddy site, except for a high rate in June at the vegetated sandy site. There was no significant difference (2-way ANOVA, p > 0.05) between the vegetated and bare muddy sites (Fig. 4). SOU was highest at the beginning of the growth season and decreased by $66 \%$ on average by September. For the sandy site, there was no significant difference between vegetated and bare sediments, except for September, where rates in the vegetated sediments were only $39 \%$ of the bare sediments (2-way ANOVA, p =0.002; Fig. 4). As for the muddy site, rates decreased by up to $82 \%$ during the growth season.

DIP fluxes showed large seasonal variations; there were more distinct differences between vegetated and bare sediments, although these were not significant due to high heterogeneity (2-way ANOVA, p > 0.05). The fluxes were highest at the muddy site, and in the vegetated sediments changed from an uptake in June

to effluxes during the rest of the period (Fig. 5). In the bare sediments, only July showed an efflux. At the sandy site, the rates were generally lower compared with the muddy site (Fig. 5). The vegetated sediments showed an efflux during the sampling period, whereas DIP was taken up, except for a small efflux in August, in the bare sediments (Fig. 5).

Only very little sedimentary $P$ $(<11 \%)$ was obtained in the loosely adsorbed $\left(\mathrm{P}_{\mathrm{MgCl}_{2}}\right)$ and Fe-bound pool $\left(\mathrm{P}_{\mathrm{BD}}\right)$ at the sandy site (Table 2, Fig. 6). The pools were at a maximum in the surface layers and decreased with depth (Fig. 6). The depth-integrated pools $(0-5 \mathrm{~cm})$ show that there is a limited difference between vegetated and bare sediments (Table 2), but there was some seasonal variation: the $\mathrm{P}_{\mathrm{BD}}$ fraction was at a maximum in June and September, and the $\mathrm{P}_{\mathrm{MgCl}_{2}}$ fraction was at a maximum in June and July and at a minimum in August. The $\mathrm{P}_{\mathrm{RES}}$ pool was 2 orders of magnitude higher than the $\mathrm{P}_{\mathrm{MgCl}_{2}}$ and $\mathrm{P}_{\mathrm{BD}}$ pools, and the full sequential extraction in September showed that the $\mathrm{P}_{\mathrm{HCl}}$ pool was the most important fraction of $\mathrm{P}_{\text {RES }}$ (Fig. 6).

At the muddy site a significant fraction of the $\mathrm{P}$ was found in the $\mathrm{P}_{\mathrm{BD}}$ pool (up to $39 \%$; Table 2), and most of it was found in the surface layer (>50\%; Fig. 6). The $\mathrm{P}_{\mathrm{BD}}$ pool was generally higher in the bare sediment (Table 2). The $\mathrm{P}_{\mathrm{MgCl}_{2}}$ pools were about 1 order of magnitude lower than the $\mathrm{P}_{\mathrm{BD}}$ pool, and there was a minor

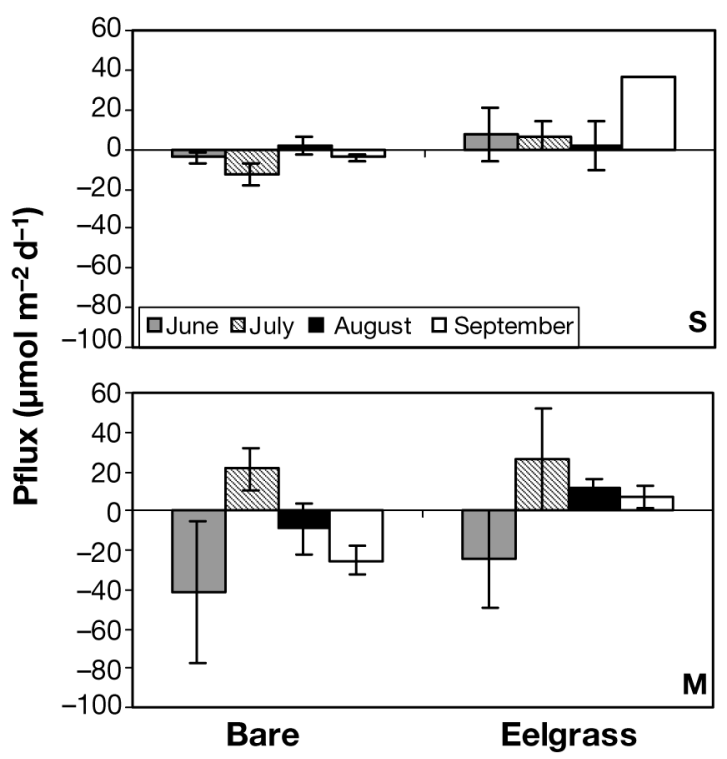

Fig. 5. P fluxes in vegetated (eelgrass) and bare sediment from muddy $(\mathrm{M})$ and sandy $(\mathrm{S})$ site during the sampling period. The standard deviation is not shown for the vegetated site in September due to a very high value $\left( \pm 81 \mathrm{mmol} \mathrm{m}^{-2} \mathrm{~d}^{-1}\right.$; $\mathrm{n}=3, \pm \mathrm{SD}$ ) 
difference between vegetated and bare sediments (Table 2). The full sequential extraction showed that about $50 \%$ of the $\mathrm{P}$ in the vegetated sediments was bound in $\mathrm{P}_{\mathrm{RES}}$, whereas the $\mathrm{P}_{\mathrm{BD}}$ fraction in the surface layer and the $\mathrm{P}_{\mathrm{HCl}}$ fraction in the deepest layer contributed significant to the TP (50 and 59\%, respectively) in the bare sediments (Fig. 6).

Table 2. Seasonal rhizosphere pools ( $0-5 \mathrm{~cm}$ sediment depth) of $\mathrm{P}$ and $\mathrm{Fe}$ from sequential extractions at the 2 study sites. $\mathrm{P}_{\mathrm{RES}}$ for September were obtained by summation of $\mathrm{P}$ in Steps 3 to 5 of the sequential P-extraction procedure. The molar ratio between $\mathrm{P}_{\mathrm{BD}}$ and $\mathrm{Fe}_{\mathrm{BD}}$ is given. All pools are given in $\mathrm{mmol} \mathrm{m} \mathrm{m}^{-2}$ and represent 3 pooled cores

\begin{tabular}{|c|c|c|c|c|c|}
\hline & \multicolumn{3}{|c|}{ P content } & \multirow{2}{*}{$\begin{array}{c}\text { Fe content } \\
\mathrm{Fe}_{\mathrm{BD}}\end{array}$} & \multirow{2}{*}{$\begin{array}{c}\mathrm{Fe}_{\mathrm{BD}}: \mathrm{P}_{\mathrm{BD}} \\
\text { (molar) }\end{array}$} \\
\hline & $\mathrm{P}_{\mathrm{MgCl}_{2}}$ & $\mathrm{P}_{\mathrm{BD}}$ & $\mathrm{P}_{\mathrm{RES}}$ & & \\
\hline \multicolumn{6}{|c|}{ Sandy bare } \\
\hline Jun & 12.0 & 9.1 & 276.2 & 71 & 7.8 \\
\hline Jul & 10.5 & 5.8 & 298.8 & 51 & 8.8 \\
\hline Aug & 5.4 & 6.8 & 278.1 & 76 & 11.1 \\
\hline Sep & 7.8 & 28.5 & 269.0 & 84 & 3.0 \\
\hline \multicolumn{6}{|c|}{ Sandy vegetated } \\
\hline Jun & 10.4 & 12.0 & 289.9 & 62 & 5.1 \\
\hline Jul & 10.4 & 4.3 & 261.8 & 43 & 10.2 \\
\hline Aug & 5.3 & 10.6 & 319.9 & 84 & 7.9 \\
\hline Sep & 8.8 & 13.0 & 259.0 & 73 & 5.6 \\
\hline \multicolumn{6}{|c|}{ Muddy bare } \\
\hline Jun & 8.0 & 248.3 & 622.0 & 6375 & 25.7 \\
\hline Jul & 6.3 & 167.6 & 184.0 & 4369 & 26.1 \\
\hline Aug & 9.7 & 160.0 & 633.9 & 3404 & 21.3 \\
\hline Sep & 8.2 & 168.2 & 1050.4 & 4446 & 26.4 \\
\hline \multicolumn{6}{|c|}{ Muddy vegetated } \\
\hline Jun & 7.4 & 150.9 & 633.7 & 4977 & 33.0 \\
\hline Jul & 6.0 & 168.0 & 274.5 & 4497 & 26.8 \\
\hline Aug & 9.3 & 120.0 & 602.2 & 2370 & 19.8 \\
\hline Sep & 9.2 & 81.8 & 755.7 & 2307 & 28.2 \\
\hline
\end{tabular}

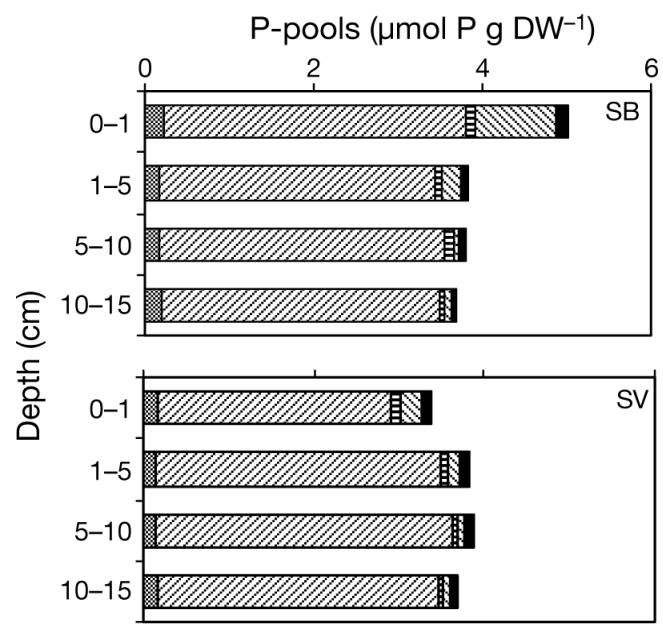

Only depth-integrated pools of $\mathrm{Fe}_{\mathrm{BD}}$ are presented, and they show much higher values at the muddy site ( 2307 to $6375 \mathrm{mmol} \mathrm{m}^{-2}$ ) than at the sandy site (43 to $84 \mathrm{mmol} \mathrm{m}^{-2}$ ), corresponding to the low $\mathrm{P}_{\mathrm{BD}}$ (Table 2). At both the sandy and muddy sites, pools were generally similar or lower in the vegetated sediments than in the bare sediments. The $\mathrm{Fe}_{\mathrm{BD}}: \mathrm{P}_{\mathrm{BD}}$ ratios were much lower at the sandy site (3 to 11) compared with the muddy site (15 to 24 ; Table 2 ). At the sandy site the ratios were at maximum in July and August, whereas the opposite pattern was found for the muddy site.

The rhizosphere pools of total reducible sulphides (TRS) were about 1 order of magnitude higher at the muddy site compared with the sandy site, and maximum pools were found in July (Table 3). The pools were generally higher at the vegetated muddy site

Table 3. Seasonal variation in rhizosphere pools $(0-5 \mathrm{~cm})$ of total reduced sulfide pools at the 2 study sites (TRS, mmol $\mathrm{S} \mathrm{m}^{-2}$ ), and the ratio between vegetated and bare sediments (Veg:bare) for the TRS, $\mathrm{P}_{\mathrm{BD}}$ and $\mathrm{Fe}_{\mathrm{BD}}$ pools in the rhizosphere sediment. Average values of 3 cores are given for TRS. -: not available

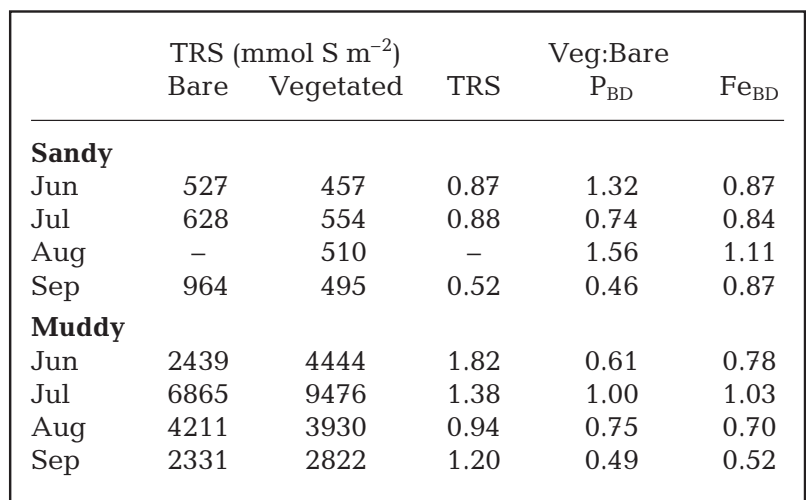

\section{P-pools ( $\left.\mu \mathrm{mol} \mathrm{P} \mathrm{g} \mathrm{DW}{ }^{-1}\right)$}

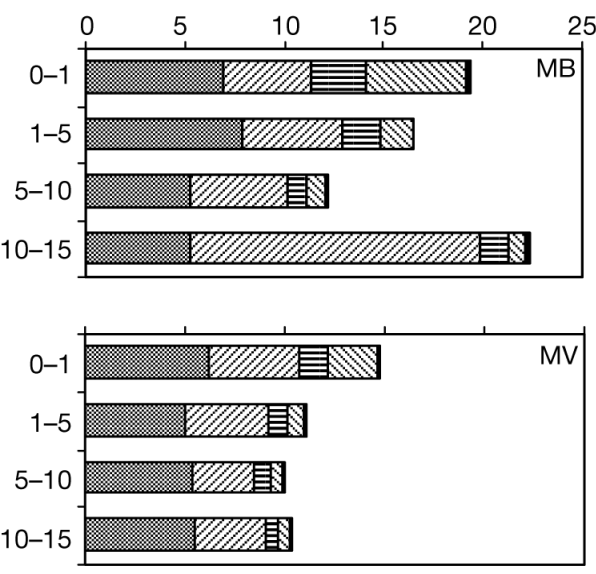

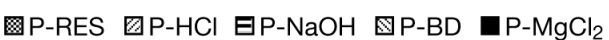

Fig. 6. P pools in September at vegetated (V) and bare (B) sediments from sandy (S) and muddy (M) sites 
compared to the bare site (20 to $82 \%$ ), whereas the opposite pattern was found at the sandy site (12 to $48 \%$ lower at the vegetated site). The AVS pools accounted for $<10 \%$ of the TRS pool at both sites (data not shown).

The redox profiles generally showed that both bare and vegetated sediments were reduced in the deeper layers ( $>5 \mathrm{~cm}$, Fig. 7). At the sandy site, the surface layers in the vegetated sediment had lower redox potential than for those in the bare sediment, whereas the opposite was found for the deeper layers (Fig. 7). In contrast, the muddy site had higher redox potentials in the surface layers, whereas the deeper layers were more negative in the vegetated sediment compared with the bare sediment. At the sandy site, the sediments were generally most reduced in August, whereas at the muddy site, the September sampling showed the lowest values.

The organic content was lowest at the sandy site $(\sim 0.5 \% \mathrm{DW})$, with no significant difference between

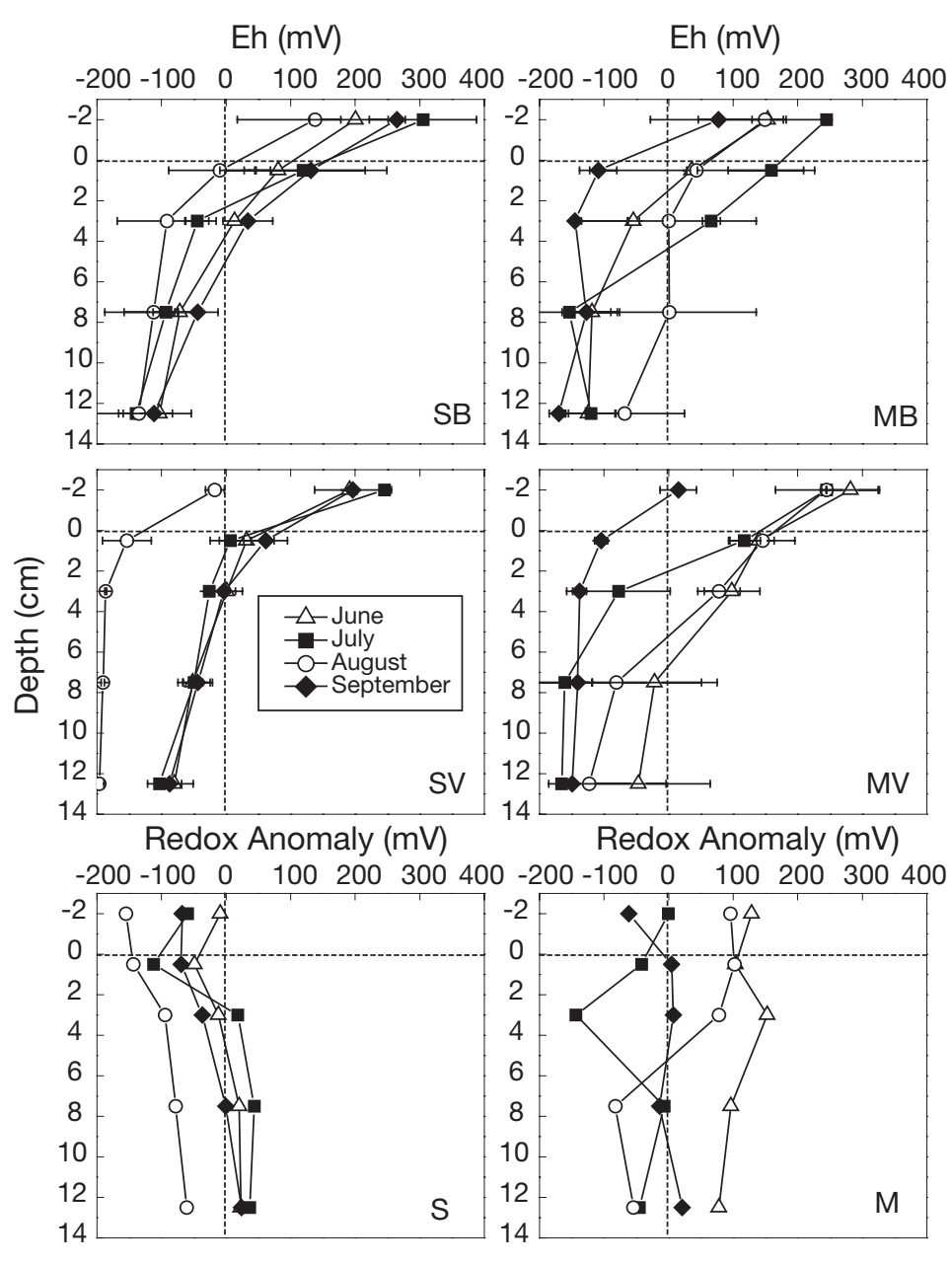

Fig. 7. Seasonal variation in depth profiles of sediment redox potential $\left(E_{\mathrm{h}}\right)$ in bare $(\mathrm{B})$ and vegetated $(\mathrm{V})$ sediment from sandy (S) and muddy $(\mathrm{M})$ sediments $(\mathrm{n}=3, \pm \mathrm{SD})$. Redox anomaly $\left[E_{\mathrm{h}}(\mathrm{V})-\right.$ $\left.E_{\mathrm{h}}(\mathrm{B})\right]$ is shown in the lowest panel for sandy and muddy sediments
Table 4. Seasonal variation in depth-averaged sediment organic matter $(\mathrm{OM})$ in bare and vegetated sediments at sandy and muddy site ( $\% \mathrm{DW}, \mathrm{n}=3, \pm \mathrm{SD})$

\begin{tabular}{|lcc|}
\hline & Bare OM & Vegetated OM \\
\hline Sandy & & \\
Jun & $0.41 \pm 0.08$ & $0.43 \pm 0.05$ \\
Jul & $0.44 \pm 0.04$ & $0.47 \pm 0.04$ \\
Aug & $0.56 \pm 0.05$ & $0.56 \pm 0.09$ \\
Sep & $0.52 \pm 0.09$ & $0.45 \pm 0.07$ \\
Muddy & & \\
Jun & $2.37 \pm 0.43$ & $1.62 \pm 1.18$ \\
Jul & $1.86 \pm 0.56$ & $4.81 \pm 1.86$ \\
Aug & $1.69 \pm 0.22$ & $1.44 \pm 0.36$ \\
Sep & $1.48 \pm 0.57$ & $1.32 \pm 0.28$ \\
\hline
\end{tabular}

the vegetated and bare sediments and no significant seasonal variation (Table 4). At the muddy site, a few high values in July, which may have been root detritus in the deeper layers, resulted in a high average content $(4.8 \% \mathrm{DW})$, whereas the other samplings were in a range similar to that found for the bare site $(1.5$ to $2.4 \% \mathrm{DW})$. There was a decreasing trend during the sampling period, but it was not significant $(p>0.05)$.

\section{DISCUSSION}

\section{General sediment biochemistry}

The biogeochemical conditions of the rhizosphere sediments of the 2 eelgrass meadows differed considerably, in particular regarding the organic content, redox conditions, sulphide pools and the sedimentary forms of $\mathrm{P}$. The organic content was, as expected, higher at the muddy site, but in contrast to other findings the presence of eelgrass did not increase the organic content significantly compared with the unvegetated sediments (Holmer et al. 2003b, Duarte et al. 2004). The lack of difference between the examined meadows may suggest that the meadows have been established recently (Pedersen et al. 1997, Pérez et al. 2001, Barrón et al. 2004), but both meadows are located at shallow depth and resuspension events may reposition the detritus pools and minimize the difference between bare and vegetated sediments (Frederiksen et al. 2004).

The modification of redox profiles due to presence of vegetation suggests that eelgrass is able to alter the biogeochemical conditions of the sediments. At the muddy site a positive anomaly was found in the surface layers and a negative anomaly in the deeper layers, whereas the sandy site 
showed the opposite pattern except for September, when the redox values were very low throughout the profile. Studies of other seagrass species have shown a positive anomaly throughout the root zone during the growth season (Zostera noltii, Isaksen \& Finster 1996; Thalassia testudinum, Enríquez et al. 2001; Cymodocea nodosa, Marbà \& Duarte 2001), whereas a seasonal study of $C$. nodosa documented negative values in the surface layers at the beginning and end of the growth season (Marbà \& Duarte 2001). The positive anomaly at our study sites was coincident with the maximum below-ground biomass, and oxygen release from the roots may contribute to increased oxidation of the sediments compared with unvegetated sites (Pedersen et al. 2004). The negative anomaly in the sandy surface sediments could be due to the presence of labile organic matter, e.g. from microphytobenthos or seston settling in the seagrass meadow (Gacia et al. 2002) leading to increased microbial activity and consumption of oxygen.

The total pool of iron was about 20 times higher at the muddy site than at the sandy site, and this was clearly affecting the $\mathrm{Fe}_{\mathrm{BD}}$, the values for which were up to 70 times higher at the muddy site. Despite the high accumulation of reduced sulphides at the muddy site, the iron availability was apparently sufficient to allow a higher accumulation of oxidized iron compared with the sandy site. The presence of eelgrass decreased the pools of $\mathrm{Fe}_{\mathrm{BD}}$, in particular at the muddy site, which may be a mechanism by which $\mathrm{P}$ availability is increased for plant uptake. The $\mathrm{P}_{\mathrm{BD}}$ was, however, still between 6 to 27 times higher at the muddy site than at the sandy site, and it is thus likely that very limited iron was available for binding of $\mathrm{P}$ and sulphide precipitation at the sandy site, which minimizes the pools of iron sulphides as well as the $\mathrm{P}_{\mathrm{BD}}$ pools and may exert an anoxic and sulphide stress on the seagrasses (Terrados et al. 1999, Pedersen et al. 2004).

\section{P dynamics in sedimentary pools}

Based on the higher organic matter content and the high iron pools at the muddy site, it is expected that the $\mathrm{P}$ availability for plant uptake was higher there than at the sandy site. $\mathrm{P}_{\mathrm{BD}}$ dominated the solid-phase $\mathrm{P}$ pools at the muddy site, whereas calcium-bound $\mathrm{P}\left(\mathrm{P}_{\mathrm{HCl}}\right)$ dominated at the sandy site, accounting for about 30 and $90 \%$ of the TP pool, respectively. The pools at the muddy site are within the lower range reported for coastal siliclastic sediments (Jensen et al. 1995), whereas the pools at the sandy site are similar to low-P carbonate sediments (Jensen et al. 1998, Koch et al. 2001). The most easily available $P$ pools for mobilization and plant uptake in siliclastic and clay-dominated sediments are considered to be the fractions extracted in the $\mathrm{MgCl}_{2}$ and BD treatments (Jensen et al. 1995, 1998, McGlathery et al. 2001). The $\mathrm{MgCl}_{2}$ extraction is considered to contain P loosely adsorbed to the sediments, and although this pool depends strongly on the adsorption sites and thus was expected to differ between the fine-grained muddy and coarse-grained sandy sediments (Jensen et al. 1995), the pool was quite similar in the 2 sediment types, with no major differences between bare and vegetated sediments, suggesting that neither the sediment type nor the activity of the plants affected this pool at the examined locations. Whereas there was no effect of season on the $\mathrm{P}_{\mathrm{MgCl}_{2}}$ pools in the 2 sediments types, the $\mathrm{P}_{\mathrm{BD}}$ pool was lower at the muddy site in the late growth season, coincident with low $\mathrm{Fe}_{\mathrm{BD}}$ pools. Depletion of oxidized iron pools due to high sulphate reduction activity and low reoxidation capacity during late summer has been found for unvegetated sediments (Jensen et al. 1995, Holmer et al. 2003a), and this is consistent with the low redox potentials measured in September. The $\mathrm{P}_{\mathrm{BD}}$ pools were generally lower in the vegetated sediment compared to the bare sediments, in particular at the rooted depths, which may reflect an uptake by the plants (McGlathery et al. 2001). At the sandy site the $\mathrm{P}_{\mathrm{BD}}$ pools were lowest during July and August, when the pools of $\mathrm{Fe}_{\mathrm{BD}}$ also were lower, suggesting that $\mathrm{P}$ was released due to reduction of oxidized iron. The low redox potentials measured in the surface layer of the sandy sediments further support reduction of iron oxides and release of P. A similar pattern with release of $\mathrm{P}$ from $\mathrm{Fe}$ oxyhydroxides during summer has been found in a Ruppia cirrhosa meadow (Azzoni et al. 2001).

The large difference in $\mathrm{P}$ and Fe pools in the BD fraction at the sandy and muddy sites resulted in a major difference in the $\mathrm{Fe}_{\mathrm{BD}}: \mathrm{P}_{\mathrm{BD}}$ ratios, with high ratios at the muddy site (16 to 24 ) and low ratios at the sandy site (3 to 11$)$. The ratios at the muddy site are similar to findings in deep parts of the Skagerrak ( 700 m; Jensen \& Thamdrup 1993), where iron minerals are considered to be either less capable of adsorbing DIP or less saturated with DIP compared with more shallow locations with lower $\mathrm{Fe}_{\mathrm{BD}}: \mathrm{P}_{\mathrm{BD}}$ ratios. The $\mathrm{P}$ pools were lower at the muddy site compared with the Skagerrak, in particular in the vegetated sediments, which may be due to plant uptake. The low ratios and the seasonal variation with lower ratios during late summer at the sandy site were similar to observations in coastal surface sediment (water depth 16 m; Jensen et al. 1995). Such low ratios have been taken to indicate the limit for iron to bind $\mathrm{P}$ in freshwater sediments (Jensen et al. 1992), and it is thus likely that the low availability of oxidized iron is the limiting factor for binding of $\mathrm{P}$ in the $\mathrm{BD}$ fraction at the sandy site. Despite the large difference 
in $\mathrm{P}_{\mathrm{BD}}$ pools between the sandy and muddy sites, the depth-integrated pools of TP were at a maximum 2 times higher at the muddy site as a result of the relatively large pool of calcium-bound $\mathrm{P}$ at the sandy site. This indicates that the overall burial of $\mathrm{P}$ was not that different in the 2 types of sediment.

Even though the differences between vegetated and bare sediments were small for SOU, suggesting small differences in organic-matter mineralisation rates, higher $\mathrm{P}$ fluxes in the vegetated sediments indicated higher $\mathrm{P}$ availability. Dissolved inorganic phosphate was released from the muddy vegetated sediments from July to September, whereas efflux only was observed from the bare sediments in July, and at the sandy site there was a P efflux from the vegetated sediments during the entire sampling period and only in August for the bare sediments. There are only few observations of $\mathrm{P}$ fluxes in seagrass sediments, but for Thalassia testudinum a release of DIP was found for an anthropogenically affected site, probably due to higher mineralisation of organic-matter inputs, whereas the pristine sites showed an uptake of DIP (Jensen et al. 1998). However, the measured release in our study was low compared with the large changes in the sedimentary pools of $\mathrm{P}$ and could at maximum account for $10 \%$ of the observed changes in the surface sedimentary pools between samplings.

\section{Implications of sedimentary $\mathbf{P}$ pools for $\mathbf{P}$ dynamics in eelgrass tissues}

In contrast to the quite similar nitrogen content in the leaves, the $\mathrm{P}$ content was between 26 and $233 \%$ higher at the muddy site than at the sandy site, which is similar to observations by Short (1987), where eelgrass accumulated higher P pools in muddy compared with sandy substrates. There were quite different patterns of seasonal variation, with continuously increasing $\mathrm{P}$ concentrations at the sandy site, whereas the P maximum was reached in July at the muddy site and had decreased $31 \%$ by September. The muddy site was characterized by the highest efflux of $\mathrm{P}$, in particular in July, which may explain the higher $\mathrm{P}$ content in the leaves in this period. However, most $\mathrm{P}$ uptake for seagrasses is believed to occur through the roots (McRoy et al. 1972), although recent studies of Thalassia testudinum growing on carbonate sediments have shown a larger uptake by leaves due to the strong binding of $\mathrm{P}$ to the sedimentary pools (Gras et al. 2003). There were no signs of P-limited growth at the muddy site, as the $\mathrm{P}$ concentrations in the leaf tissues were above the critical limits for growth (Duarte 1990). In contrast, the P content was below the critical limit at the sandy site, in particular at the beginning of the growth season, suggesting $\mathrm{P}$ limitation in this sediment, where a significantly part of the $\mathrm{P}$ is bound in the calcium fraction. An additional indication of enhanced $\mathrm{P}$ availability for root uptake at the muddy site was the up to 2 times higher $\mathrm{P}$ content in the below-ground tissues compared with the sandy site. Also, the $\mathrm{N}$ content of the below-ground tissues was higher, up to 3 times, suggesting that mineralisation of organic matter may contribute nutrients to the plants. However, the evaluation of nutrient limitation on seagrass growth based solely on nutrient content should be done with caution, as both $\mathrm{P}$ and $\mathrm{N}$ can be translocated in the plants for growth optimisation (Pedersen \& Borum 1992, Alcoverro et al. 2000, Gras et al. 2003).

To our knowledge there are no estimates of the $\mathrm{P}$ requirements of Zostera marina for growth, whereas rates of 30 to $100 \mu \mathrm{mol} \mathrm{P} \mathrm{m}{ }^{-2} \mathrm{~d}^{-1}$ have been estimated for Thalassia testudinum (Patriquin 1972, Fourqueran et al. 1992). We did not measure primary productivity, but estimates can be made by assuming an annual production of $\sim 818 \mathrm{~g} \mathrm{DW} \mathrm{m}^{-2} \mathrm{yr}^{-1}$ by $Z$. marina based on extensive studies of meadows located under similar conditions (from Olesen \& Sand-Jensen 1994). The average leaf $\mathrm{P}$ concentration was $60 \mu \mathrm{mol} \mathrm{P} \mathrm{g} \mathrm{DW} \mathrm{DW}^{-1}$ and $110 \mu \mathrm{mol} \mathrm{P} \mathrm{g} \mathrm{DW}{ }^{-1}$ for sandy and muddy sediments, respectively, and the annual $P$ requirements are thus 49 and $90 \mathrm{mmol} \mathrm{P} \mathrm{m}^{-2} \mathrm{yr}^{-1}$, respectively. The below-ground biomass was only estimated in September, and, assuming a production of $130 \mathrm{~g} \mathrm{DW} \mathrm{m}^{-2} \mathrm{yr}^{-1}$ (Z. noltii, from Duarte et al. 1998), the P requirements can be estimated to be 3 and $5 \mathrm{mmol} \mathrm{P} \mathrm{m}^{-2} \mathrm{yr}^{-1}$ at the sandy and muddy sites, respectively. The total $\mathrm{P}$ requirements are then 52 and $95 \mathrm{mmol} \mathrm{P} \mathrm{m}^{-2} \mathrm{yr}^{-1}$, and, assuming that most of the uptake occurs during the growth season examined here, the release of $\mathrm{P}$ across the sediment-water interface can only support a fraction of this amount (average rate $5 \mu \mathrm{mol} \mathrm{m} \mathrm{m}^{-2} \mathrm{~d}^{-1}$, max. $2 \%$ ). The water-column concentration of DIP was low during the growth period ( $<1 \mu \mathrm{M}$, data not shown), and the water column should be fully mixed all the time to be able to support the estimated plant requirements. This suggests that the sedimentary pools play the most important role for $\mathrm{P}$ uptake, and the observed seasonal changes in the loosely adsorbed $\mathrm{P}_{\mathrm{MgCl}_{2}}$ and $\mathrm{P}_{\mathrm{BD}}$ pools were almost sufficient to support plant uptake at the muddy site, as the surface sedimentary pools were reduced by $86 \mathrm{mmol} \mathrm{m}^{-2}$ from July to September. However, at the sandy site the changes in sedimentary $\mathrm{P}_{\mathrm{MgCl}_{2}}$ and $\mathrm{P}_{\mathrm{BD}}$ pools were much lower and could not support plant growth, and this may explain the low $\mathrm{P}$ contents in plant tissues and the lower biomass of the meadow. Similarly, Jensen et al. (1998) found that the water-column pools of DIP were too low to support seagrass $\mathrm{P}$ requirements for $T$. testudinum, and a release of $\mathrm{P}$ from the particulate $\mathrm{P}$ pools of the sediment was 
necessary to renew the porewater DIP for direct uptake by the roots or for $\mathrm{P}$ release across the sediment-water interface. They found that the sedimentary pools could only support long-term seagrass growth if these were available for plant uptake, and the same conclusion can be made for this study, where the total sedimentary $P$ pools exceeded by several times the amount required by the plants, and even the easily available pools, such as the $\mathrm{P}_{\mathrm{MgCl}_{2}}$ and $\mathrm{P}_{\mathrm{BD}}$ pools, were 6 to 100 times higher than the requirements at the muddy site. However, P limitation may occur if the release of $\mathrm{P}$ from the particulate sedimentary pools is too slow to support maximum growth rates. This may be the case at the sandy site with high pools of calcium-bound $\mathrm{P}$.

In conclusion, the large pools of easily available $\mathrm{P}$ at the muddy site, which become available during the growth season through increased mineralisation of organic matter due to increasing temperatures and reduction of the rhizosphere sediments, thereby releasing $\mathrm{P}$ from the redox-sensitive pools, provide $\mathrm{P}$ for plant uptake, and no P limitation was observed. In contrast, the availability of $\mathrm{P}$ was lower at the sandy site, as $\mathrm{P}$ was bound in the calcium fraction, which is more resistant to seasonal changes in sediment biogeochemical conditions.

Acknowledgements. We thank C. Kronborg for technical assistance during laboratory work, and T. Rützou and B. B. Knudsen for their help during field work. C.C. was supported by a grant from the Government of Sardinia, and M.H. and F.Ø.A. by a grant from the National Science Foundation (grant no. 21-02-0463, 272-05-0408).

\section{LITERATURE CITED}

Alcoverro T, Duarte CM, Romero J (1997) The influence of herbivores on Posidonia oceanica epiphytes. Aquat Bot 56: 93-104

Alcoverro T, Manzanera M, Romero J (2000) Nutrient mass balance of the seagrass Posidonia oceanica: the importance of nutrient retranslocation. Mar Ecol Prog Ser 194: $13-21$

Azzoni R, Giodani G, Bartoli M, Welsh DT, Viaroli P (2001) Iron, sulphur and phosphorus cycling in the rhizosphere sediments of a eutrophic Ruppia cirrhosa meadow (Valle Smarlacca, Italy). J Sea Res 45:15-26

Barrón C, Marbà N, Terrados J, Kennedy H, Duarte CM (2004) Community metabolism and carbon budget along a gradient of seagrass (Cymodocea nodosa) colonization. Limnol Oceanogr 49:1642-1651

Brix H, Lyngby JE (1985) Uptake and translocation of phosphorus in eelgrass (Zostera marina). Mar Biol 90:111-116

Canfield DE (1993) Organic matter oxidation in marine sediments. In: Wollast, R, Mackenzie FT, Chou L (eds) Interactions of $\mathrm{C}, \mathrm{N}, \mathrm{P}$, and $\mathrm{S}$ biochemical cycles and global change. Springer-Verlag, Berlin, p 333-363

Cline JD (1969) Spectrophometric determination of hydrogen sulfide in natural waters. Limnol Oceanogr 14:454-458
Duarte CM (1990) Seagrass nutrient contents. Mar Ecol Prog Ser 67:201-207

Duarte CM, Middelburg JJ, Caraco N (2004) Major role of marine vegetation on the oceanic carbon cycle. Biogeosci Discuss 1:659-679

Enríquez S, Marbà N, Duarte CM, van Tussenbroek BI, Reyes-Zavala G (2001) Effects of seagrass Thalassia testudium on sediment redox. Mar Ecol Prog Ser 219: $149-158$

Fossing H, Jørgensen BB (1989) Measurement of bacterial sulfate reduction in sediments: evaluation of a single-step chromium reduction method. Biogeochemistry 8:205-222

Fourqueran JW, Zieman JC, Powell GVN (1992) Phosphorus limitation of primary production in Florida Bay: evidence from the C:N:P ratios of the dominant seagrass Thalassia testudinum. Limnol Oceanogr 37:162-171

Frederiksen M, Krause-Jensen D, Holmer M, Laursen JS (2004) Spatial and temporal variation in eelgrass (Zostera marina) landscapes: influence of physical setting. Aquat Bot 78:147-165

Gacia E, Duarte C M, Middelburg JJ (2002) Carbon and nutrient deposition in a Mediterranean seagrass (Posidonia oceanica) meadow. Limnol Oceanogr 47:23-32

Gras AF, Koch MS, Madden CJ (2003) Phosphorus uptake kinetics of a dominant tropical seagrass Thalassia testudinum. Aquat Bot 76:299-315

Hemminga MA (1998) The root/rhizome system of seagrasses: an asset and burden. J Sea Res 39:183-196

Holmer M, Laursen L (2002) Effect of shading of Zostera marina (eelgrass) on sulfur cycling in sediments with contrasting organic matter and sulfide pools. J Exp Mar Biol Ecol 270:25-37

Holmer M, Ahrensberg N, Jørgensen NP (2003a) Impacts of mussel dredging on sediment dynamics in an eutrophic Danish fjord. Chem Ecol 19:343-362

Holmer M, Duarte CM, Marbá N (2003b) Sulfur cycling and seagrass (Posidonia oceanica) status in carbonate sediments. Biogeochemistry 66:223-239

Isaksen MF, Finster K (1996) Sulphate reduction in the root zone of the seagrass Zostera noltii on the intertidal flats of a coastal lagoon (Arcachon, France). Mar Ecol Prog Ser 137:187-194

Jensen HS, Thamdrup B (1993) Iron-bound phosphorus in marine sediments as measured by bicarbonate-dithionite extraction. Hydrobiologia 253:47-59

Jensen HS, Kristensen P, Jeppesen E, Skytthe A (1992) Iron:phosphorus ratio in surface sediments as an indicator of phosphate release form aerobic sediments in shallow lakes. In Hart BT, Sly PG (eds) Sediment/water interactions. Developments in hydrobiology, Vol 75. Kluwer Academic Publishers, Dordrecht, p 731-743

Jensen HS, Mortensen PB, Andersen FØ, Rasmussen E, Jensen A (1995) Phosphorus cycling in costal marine sediment, Aarhus Bay, Denmark. Limnol Oceanogr 40:908-917

Jensen HS, McGlathery KJ, Marino R, Howarth RW (1998) Forms and availability of sediment phosphorus in carbonate sand of Bermuda seagrass beds. Limnol Oceanogr 43: 799-810

Koch MS, Benz RE, Rudnick DT (2001) Solid-phase phosphorus pools in highly organic carbonate sediments of northeastern Florida Bay. Estuar Coast Shelf Sci 52:279-291

Koroleff F (1983) Determination of nutrients. In: Grasshof K, Ehrhardt M, Kremling K (eds) Methods of seawater analysis. Verlag Chemie, Weinheim, p 125-139

Marbà N, Duarte CM (2001) Growth and sediment space occupation by seagrass Cymodocea nodosa roots. Mar Ecol Prog Ser 224:291-298 
McGlathery KJ, Berg P, Marino R (2001) Using porewater profiles to assess nutrient availability in seagrass-vegetated carbonate sediments. Biogeochemistry 56:239-236

McRoy CP, Barsdate RJ (1970) Phosphate absorption in eelgrass. Limnol Oceanogr 15:6-16

McRoy CP, Nebert M, Barsdate RJ (1972) Phosphorus cycling in an eelgrass (Zostera marina L.) ecosystem. Limnol Oceanogr 17:58-68

Murray L, Dennison WC, Kemp WM (1992) Nitrogen versus phosphorus limitation for growth of an estuarine population of eelgrass (Zostera marina L.). Aquat Bot 44:83-100

Nielsen SL, Sand-Jensen K, Borum J, Geertz-Hansen O (2002) Depth colonization of eelgrass (Zostera marina L.) and macroalgae as determined by water transparency in Danish coastal waters. Estuaries 25:1025-1032

Olesen B, Sand-Jensen K (1994) Biomass-density patterns in the temperate seagrass Zostera marina. Mar Ecol Prog Ser 109:283-291

Patriguin DG (1972) Origin of nitrogen and phosphorus for growth of marine angiosperm Thalassia testudinum growth. Mar Biol 15:35-45

Pedersen MF, Borum J (1992) Nitrogen dynamics of eelgrass Zostera marina during a late summer period of high growth and low nutrient availability. Mar Ecol Prog Ser 80:65-73

Pedersen MF, Duarte CM, Cebrián J (1997) Rates of changes in organic matter and nutrient stocks during Cymodocea nodosa colonization and stand development. Mar Ecol Prog Ser 159:29-36

Pedersen O, Binzer T, Borum J (2004) Sulphide intrusion in eelgrass (Zostera marina L.). Plant Cell Environ 27:

Editorial responsibility: Otto Kinne (Editor-in-Chief),

Oldendorf/Luhe, Germany
$595-602$

Pérez M, Mateo MA, Alcoverro T, Romero J (2001) Variability in detritus stocks in beds of the seagrass Cymodocea nodosa. Bot Mar 44:523-531

Roden EE, Edmonds JW (1997) Phosphate mobilization in iron-rich anaerobic sediments: microbial Fe(III) oxide reduction versus iron-sulfide formation. Arch Hydrobiol 139:347-378

Sfriso A, Marcomini A (1999) Macrophyte production in a shallow coastal lagoon. Part II: Coupling with sediment, SPM and tissue carbon, nitrogen and phosphorus concentrations. Mar Environ Res 47:285-309

Short FT (1987) Effects of sediment nutrients on seagrasses literature review and mesocosm experiment. Aquat Bot 27:41-57

Sørensen J (1982) Reduction of ferric iron in anaerobic, marine sediment and interaction with reduction of nitrate and sulfate. Appl Environ Microbiol 43:319-324

Stookey LL (1970) Ferrozine-a new spectrophometric reagent for iron. Anal Chem 42:779-781

Terrados J, Duarte CM, Kamp-Nielsen L, Agawin NSR and 6 others (1999) Are seagrass growth and survival constrained by the reducing conditions of the sediment? Aquat Bot 65:175-197

Thursby GB, Harlin MM (1984) Interaction of leaves and roots of Ruppia maritime in the uptake of phosphate, ammonia and nitrate. Mar Biol 83:61-67

Touchette BW, Burkholder JAM (2000) Review of nitrogen and phosphorus metabolism in seagrasses. J Exp Mar Biol Ecol 250:133-167

Submitted: November 3, 2005; Accepted: January 27, 2006

Proofs received from author(s): July 31, 2006 